\title{
Contrasting floral morphology and breeding systems in two subspecies of Calceolaria corymbosa in Central Chile
}

\section{Morfología floral y sistemas reproductivos contrastantes en dos subespecies de Calceolaria corymbosa en Chile central}

\author{
Janinna Cisterna ${ }^{1}$ \& Maureen Murúa ${ }^{* 2,3}$ \\ ${ }^{1}$ Departamento de Ciencias Ecológicas, Facultad de Ciencias, Universidad de Chile, Casilla 653, Santiago, Chile. \\ ${ }^{2}$ Centro de Investigación en Recursos Naturales y Sustentabilidad (CIRENYS), Universidad Bernardo O'Higgins, Avenida Viel \\ 1497, Santiago, Chile. \\ ${ }^{3}$ Fundación Flores, Ministro Carvajal 30, Providencia, Santiago, Chile. \\ *maureen.murua@ubo.cl
}

\begin{abstract}
RESUMEN
En este estudio se caracterizó la morfología floral y se evaluaron aspectos básicos de la biología reproductiva en dos subespecies de Calceolaria corymbosa en Chile central. Nuestros resultados muestran que los rasgos de atracción de polinizadores fueron similares entre subespecies. No obstante, rasgos relacionados con la reproducción (e.g., hercogamia) podrían explicar las diferencias entre ellas. Adicionalmente, ambas subespecies mostraron diferentes estrategias reproductivas, donde C. corymbosa ssp. mimuloides fue una especie alógama, mientras que C. corymbosa ssp. santiaguina fue autocompatible y autogama parcial. En general, estos resultados sugieren que especies morfológicamente similares pueden presentar diferentes estrategias reproductivas posiblemente de acuerdo a su hábitat.
\end{abstract}

Calceolaria is one of the most diverse genera in America, including 250 species distributed from Mexico to Patagonia (Molau 1988). In Chile, it is represented by approximately 60 species, including herbs, scrub or subshrub, annual or perennial with opposite, whole or split leaves growing from the Coast to the Andes Mountain between the Antofagasta y Magallanes Region (Molau 1988, Ehrhart 2000). Flowers are zygomorphic and bilabiate composed by two lobes: one superior and reduced, and the other inferior and inflate. The latter lobe includes a gland or elaiophore that secrete oil as a floral reward (Vogel 1974). This unusual reward is collected by two genus of oil-collecting bees, Centris and Chalepogenus, which use the oil to larvae feeding and nest sealing (Sérsic 2004). This type of plantpollinator interaction has been described as one of the most specialized relationship in Chile, especially because most of the plant species belonging to this genus strictly depend on insect for pollination (Sérsic 2004, Murúa et al. 2014).

From the total species described for Chile, Calceolaria corymbosa Ruiz et Pav. is one of the most widely distributed in a variety of habitat types (Ehrhart 2000). Along its distribution, six subspecies have been described that are distinguished mainly by their red spot pattern on the corolla lobes, and the altitude that they inhabit (Ehrhart 2000). In general, there is poor knowledge about this species complex with the exception of two studies: one that characterized their distribution and morphology and the other includes two of the $C$. corymbosa subspecies in a 105 species phylogenetic analysis, revealing a recent $C$. corymbosa species separation (Cosacov et al. 2009). Here, we attempt to determine basic aspects of their reproductive biology and characterize some floral traits that may be important for plant reproduction in two C. corymbosa subspecies in Central Chile.

The study was performed during the spring-summer season of 2011 in two populations, one of each subspecies of C. corymbosa, that were sampled simultaneously. On the one hand, C. corymbosa subp. mimuloides (Clos) C. Ehrh. population was located in Valle Nevado (VN), approximately

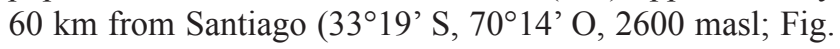
1a). This site is characterized by a mean annual temperature close to $6.5^{\circ} \mathrm{C}$, and a mean precipitation regimen of 488 mm (Cavieres \& Arroyo 1999). Plant species was located in a southwestern exposition hillside surrounding by cushing plants species of Azorella ruizii G.M. Plunkett \& A.N. Nicolas and Anarthrophyllum gayanum (A. Gray) B.D. Jacks., and some perennial and annual herbs such as Plantago barbata G. Forst., Hypochaeris tenuifolia (Hook. et Arn.) Griseb. and Montiopsis cistiflora (Gillies ex Arn. ) D.I. Ford (Cavieres et al. 2000). On the other hand, $C$. corymbosa spp. santiaguina C. Ehrh. was situated in the Reserva Nacional Río Clarillo (RC), $45 \mathrm{~km}$ from Santiago city (3346' S, $70^{\circ} 27^{\prime}$ O, 890 masl; Fig. 1b). The average annual temperature of the Reserve is around $14^{\circ} \mathrm{C}$ and its mean annual precipitation is $356 \mathrm{~mm}$ (Niemeyer et al. 2002). Plants were located along the Reserve trail at the northern hillside, mainly surrounded by Cryptocarya alba 
(Molina) Looser, Quillaja saponaria Molina and Escallonia pulverulenta (Ruiz et Pav.) Pers. (Niemeyer et al. 2002).

In each site, twenty to thirty individuals were selected and tagged; one flower per plant was photographed from a frontal and lateral perspective in the field. Then, five floral traits were digitally measured from the pictures with the software ImageJ 1.46r (online available in: http://rsb.info. nih.gov/ij/): 1) superior lobe length (LS), 2) inferior lobe

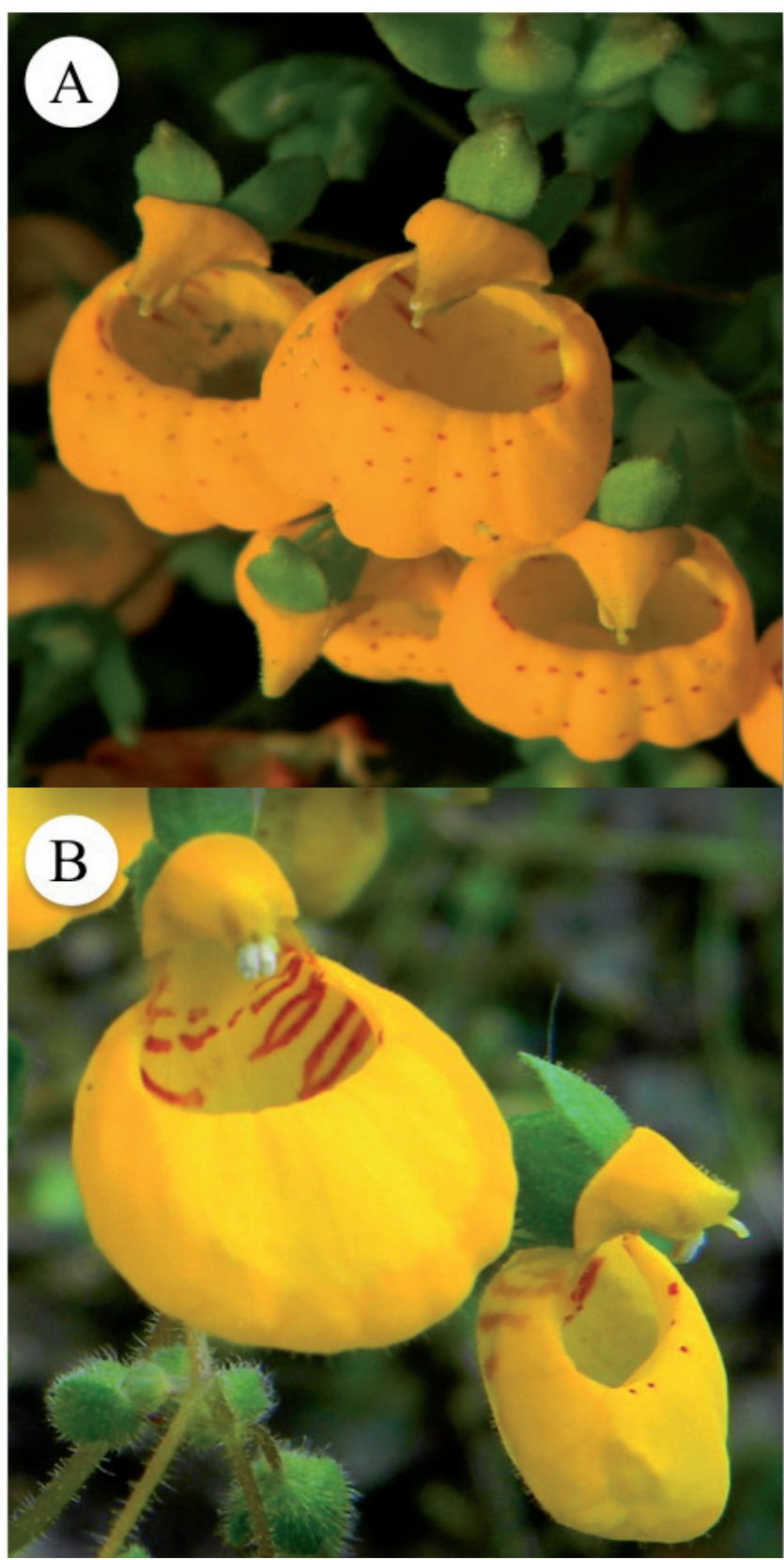

Figure 1. Floral morphology of two subspecies of Calceolaria corymbosa. (A) C. corymbosa subsp. mimuloides, and (B) C. corymbosa subsp. santiaguina. / Morfología floral de dos subespecies de Calceolaria corymbosa. (A) C. corymbosa subsp. mimuloide, y (B) C. corymbosa spp. santiaguina. length (LI), 3) stigma length (SL), 4) anthers length (AL), and 5) Hercogamy $(\mathrm{H})$, measured as the difference between SL and AL. To determine the morphological association between floral traits a Principal Component Analysis was performed. Also, in order to determine differences between subspecies the position of individuals on the axes were used to perform an ANOVA test using the subspecies factor as grouping variable. All statistical analyses were performed in $\mathrm{R}$ package version 2.15 ( $\mathrm{R}$ development Core Team 2015).

To characterize the reproductive system of each subspecies, a manipulative hand-pollination experiment was performed in twenty plants per population. For this, three buds per plant were tagged; two of them emasculated and one was left unmanipulated. Then, each bud was individually covered with a tulle mesh until the next day to ensure that the flower when opening was unpollinated. The next day, each mesh was carefully removed and one of the following pollination treatments were applied $(\mathrm{n}=$ 20 flowers per treatment per subspecies): 1) geitonogamy (G): emasculated floral bud, pollinated with pollen of the same plant and covered with a tulle mesh and, 2) xenogamy (XE): emasculated floral bud, pollinated with a mix of pollen of plants situated at least 5 meters away, and covered with a tulle mesh, and 3 ) facultative autogamy (FA): un-manipulated bud covered with the tulle mesh to exclude pollinators. In addition, an un-manipulated bud was tagged and exposed to natural pollination to be used as a control (C).

Pollination success was estimated as seed set per plant. Seeds were counted manually under magnifier 10x. Using these treatments, self-incompatibility (SII) and automatic self-pollination (ASI) indexes (Arroyo \& Uslar 1993) were estimated as follows:

$$
S I I=\frac{G}{X E} \quad A S I=\frac{F A}{G}
$$

Where FA, G, and XE represent the average seed number per fruit. Statistical differences among treatments were tested by a Kruskal-Wallis nonparametric test and a post-hoc comparison test in R software.

The principal component analysis showed that the first three PC axes explain the 55.7\%, 78.9\%, and $90.6 \%$ of the total variance. The first axis was positively correlated with high values of AL and SL and low values of $H$. The second PCA axis was positively correlated with high AL and SL values and negatively with low hercogamy values. LS and LI were the two only traits not correlated with either of the two axes. The loading factor analysis revealed that reproductive traits (AL and SL) were the responsible for most of the explaining variance, where stigma length (SL: 0.923) explained the first component and, the second component was mostly explained by anthers length (AL: 0.837). 
The two-way ANOVA test on the first principal component (PC1) showed no significant differences between subspecies $\left(\mathrm{F}_{1,49}=1.255, \mathrm{P}=0.27\right)$. While, the ANOVA test on the second principal component (PC2) showed that some floral traits condensed in this axis are responsible of subspecies differentiation $\left(\mathrm{F}_{1,49}=5.872, \mathrm{P}=\right.$ 0.02 ). Specifically, as shown in the trait-clustering plot (Fig. 2 ), traits directly related to plant reproduction (AL and SL) may be explaining subspecies variation.

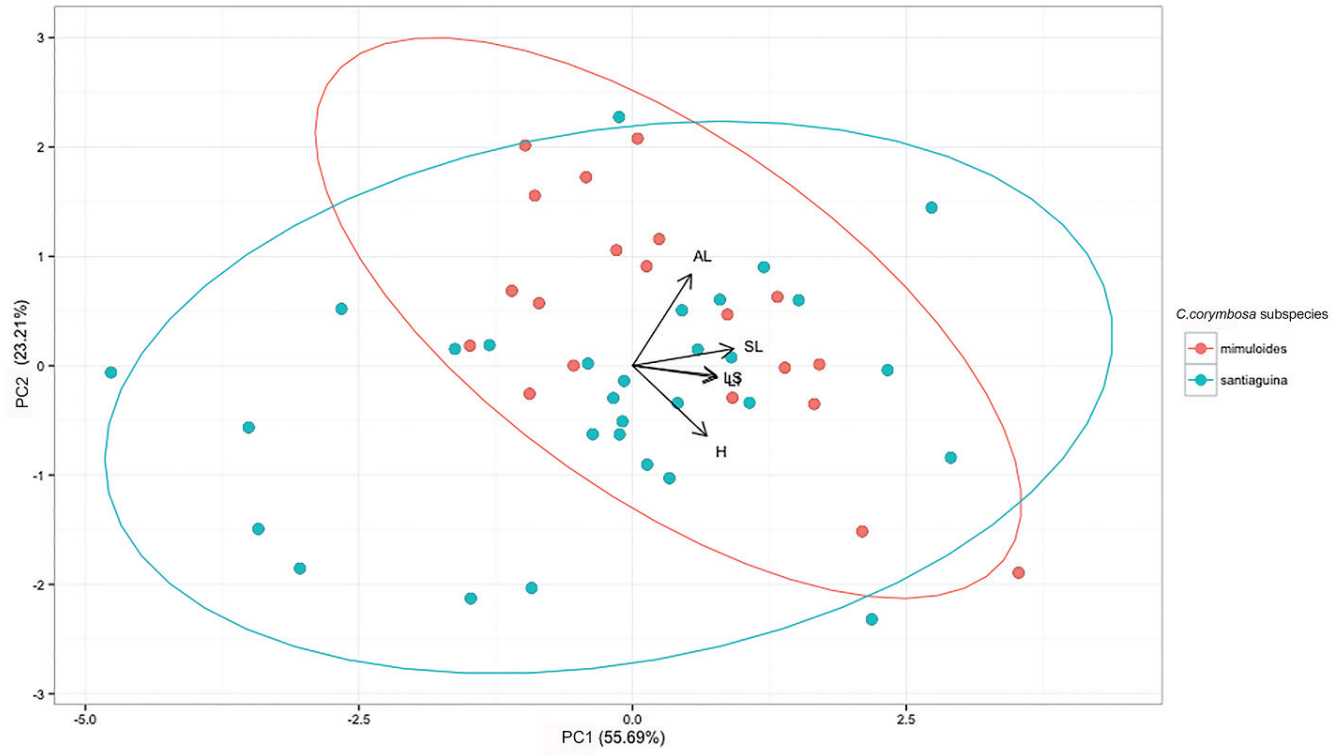

FIGURE 2. Principal component analysis (PCA) for all floral traits measured in two subspecies of Calceolaria corymbosa. Codes for floral traits are: length of the superior lobe (LS), length of the inferior lobe (LI), Stigma length (SL), anthers length (AL) and Hercogamy (H). Red circles: C. corymbosa subsp. mimuloides; Blue circles: C. corymbosa subsp. santiaguina. Percentage of explained variance is shown on the axes. / Análisis de componentes principales (ACP) para todos los rasgos florales medidos en dos subespecies de Calceolaria corymbosa. Códigos de los rasgos florales son: largo del lóbulo superior (LS), largo del lóbulo inferior (LI), largo del estigma (SL), largo de las anteras (AL) y hercogamia (H). Círculos rojos: C. corymbosa subsp. mimuloides; Círculos azules: C. corymbosa subsp. santiaguina. El porcentaje de varianza explicada se muestra en los ejes.

The comparison test revealed that there was a significant effect of treatments on seed production for both subspecies (Kruskal-Wallis, RC: $X^{2}=24.81$, df $=3, \mathrm{P}<0.0001$; VN: $X^{2}=15.22, \mathrm{df}=2, \mathrm{P}<0.0001$, Fig. 3 ). On the one hand, in C. corymbosa subsp. mimuloides population several plants were attacked by rodents, therefore, we lost some treated plants, what forced us to completely exclude the xenogamy treatment from the study. Regarding to the remaining treatments, no seed was produced under facultative autogamy treatment (FA). While, in a post-hoc comparison test, no significant differences were observed between geitonogamy (G) and control (C) treatments (Fig. 3). Finally, and due to the lost of the xenogamy treatment, the autogamy index was the only one estimated, revealing that $C$. corymbosa subsp. mimuloides is an allogamous subspecies (IAS $=0$ ). On the other hand, in C. corymbosa subsp. santiaguina population the FA treatment was also damaged by rodents, and only two of the nine remaining treated plants showed seed development. The post-hoc comparison showed significant differences between the control (C) and geitonogamy $(\mathrm{G})$ treatments, where $G$ produced more seeds per fruit than the natural pollination treatment (C, Fig. 3). Also, significant differences were observed between geitonogamy (G) and xenogamy treatment (XE), where the latter produced more seeds per fruit (Fig. 3). Finally, the automatic selfpollination (ASI $=0.19)$ and self-incompatible $(\mathrm{SII}=0.2)$ indexes reveled that $C$. corymbosa ssp. santiaguina was a partially autogamous and self-compatible subspecies.

Overall, our results showed that traits related to pollination attraction (i.e., corolla lobes) were very similar among $C$. corymbosa subspecies, however those directly related to plant reproduction (i.e., anthers and stigma length), specially the distance between the reproductive structures (i.e., hercogamy), may be good candidates to explain subspecies differences. The latter goes in accordance to the results obtained in the reproduction experiment, where both subspecies were also differentiated by the reproductive strategies used to reach plant reproductive success. Despite this fact, it is not new that most of the species are able to develop different reproductive strategies according to the 
biotic environment that surrounds them. The reproductive system of many Andean species is still unknown, especially of those species with specialized pollination system. In particular, it has been observed that Calceolaria species show a wide spectrum of reproductive strategies from complete to partial autogamy (Murúa et al. 2014), which seems to be tightly related to the availability of their specific pollinator species (i.e., oil-collecting bees). Therefore, the characterization of this ecological variability in Calceolaria seems to be a key aspect to understand the biology of these species and the nature of this unusual type of plant-pollinator relationship in Chile.

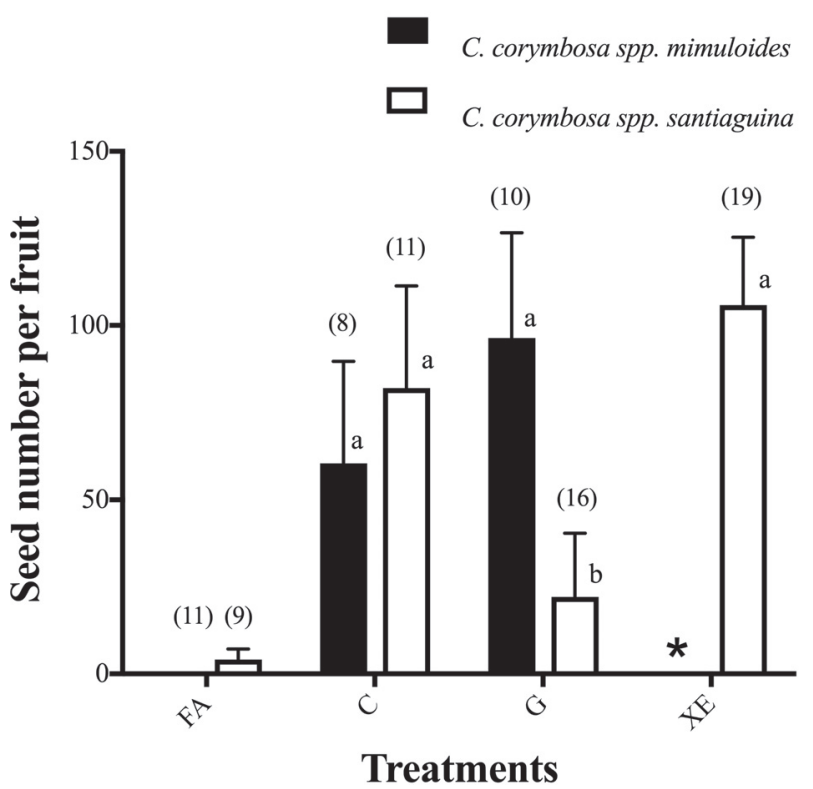

FIGURE 3. Manual pollination treatments of two subspecies of Calceolaria corymbosa. FA: facultative autogamy, C: control, G: geitonogamy and, XE: xenogamy. Values represent the mean \pm standard deviation. Sample size is presented in parenthesis. Asterisk (*) represents the treatment excluded from the analysis. To each subspecies, post-hoc comparison are showed with lowercase letter; different letters over the bars revealed statistical differences at $\mathrm{p}<$ 0.05. / Tratamientos de polinización manual de dos subespecies de Calceolaria corymbosa. FA: autogamia facultativa, C: control, G: geitonogamia y XE: xenogamia. Valores representan el promedio \pm desviación estándar. Tamaño muestreal se presenta en paréntesis. El asterisco $(*)$ representa el tratamiento que ha sido excluido del análisis. Para cada subespecie, comparaciones post-hoc se muestran en letras minúsculas; diferentes letras sobre las barras revelan diferencias significativas a $\mathrm{p}<0,05$.

Plant-pollinator specialization has been traditionally seen as a promoter of cross-pollination (Fenster et al. 2004). However, it is also known that it make some species vulnerable to pollinator fluctuations (Wilcock \& Neiland 2002), stimulating the rise of reproductive assurance mechanisms (Martén-Rodríguez \& Fenster 2010). Here, both subspecies were able to produce seeds by manual self-pollination. However, it was four times higher in C. corymbosa subsp. mimuloides than in C. corymbosa subsp. santiaguina, which could be partially explained by pollinator availability. For example, Valle Nevado, unlike Río Clarillo population, is characterized by low pollinator abundance that has been observed to decrease with the altitude (Arroyo et al. 1985, Arroyo et al. 2006). Thus, it is expected that species inhabiting high altitudes (e.g., 2800 $\mathrm{m}$ a.s.l. in the case of $C$. corymbosa subsp. mimuloides) could be experiencing higher pollen limitation than species living at low altitudes. Moreover, in Valle Nevado but not in Rio Clarillo population, at least three more Calceolaria species (e.g., C. arachnoidea Graham, C. corymbosa subsp. corymbosa and C. filicaulis Clos subsp. luxurians (Witasek) C. Ehrh.) inhabit at the same altitudinal range to C. corymbosa subsp. mimuloides (e.g., 2000-2500 masl). Hence, oil-collecting bees are solitary hymenopterans that inhabit in low densities (Sérsic 2004), so Calceolaria species coexistence might increase specialized pollinator competition and leads to the development of alternative strategies to compensate pollinator absence. Despite the fact that other non-specialized pollinators can also act as legitimate pollinators in this genus, a recent investigation has reported a tight fit between pollinator body length and flower traits related to pollen deposition (Cosacov et al. 2014, Murúa \& Espíndola 2015), suggesting an important role of these bees in the reproductive success of these plant species. Unfortunately, our study did not include data of pollinator ecology; therefore, the influence of pollinator availability on the reproduction of these plant species is still an open question. This issue needs to be addressed in future investigations, specifically to detect which are the key proximate factors that could be shaping the reproductive biology in these species.

\section{ACKNOWLEDGEMENTS}

We would like to thank to Corporación Nacional Forestal (CONAF) for fieldwork authorization. Benito Rosende for visual material and Catalina González Browne comments contribution during the development of this article. Funding was provided by Apoyo a la Realización de Tesis Doctoral, CONICYT (Folio 24110094, PI: M Murúa) and FONDECYT PD 3150267.

\section{REFERENCES}

Arroyo, M.T.K., Armesto, J.J., Primack, R.B. 1985. Community studies in pollination ecology in the high temperate Andes of central Chile II. Effect of temperature on visitation rates 
and pollination possibilities. Plant Systematic and Evolution 149: 187-203.

Arroyo, M.T.K., Muñoz, M.S., Henríquez, C., Till-bottraud, I., PÉREZ, F. 2006. Erratic pollination, high selfing levels and their correlates and consequences in an altitudinally widespread above-tree-line species in the high Andes of Chile. Acta Oecologica 30: 248-257.

Arroyo, M.T.K., Uslar, P. 1993. Breeding systems in a temperate Mediterranean-type climate montane sclerophyllous forest in central Chile. Botanical Journal of Linnean Society 111:83-102.

Cavieres, L.A., Arroyo, M.K. 1999. Lapse-rate in the Rio Molina valley, province of Santiago, central Chile $\left(33^{\circ} \mathrm{S}\right)$. Revista Geográfica Terra Australis 44: 79-86.

Cavieres, L., Peñaloza, A., Arroyo, M.T.K. 2000. Altitudinal vegetation belts in the high-Andes of central Chile $\left(33^{\circ} \mathrm{S}\right)$. Revista Chilena de Historia Natural 73: 331-344.

Cosacov, A., Cocucci, A.A., Sersic, A.N. 2014. Geographic differentiation in floral traits across the distribution range of the Patagonian oil-secreting Calceolaria polyrhiza: do pollinators mater? Annals of Botany 113: 251-266.

Cosacov, A., Sérsic, A., Sosa, V., De-Nova, A., Nylinder, S., CocCUCI, A.A. 2009. New insights into the phylogenetic relationships, character evolution, and phylogeographic patterns of Calceolaria (Calceolariaceae). American Journal of Botany 96 (2): 2240-2255.

Ehrhart, C. 2000. Die Gattung Calceolaria (Scrophulariaceae) in Chile. Bibliotheca Botanica 153: 1-283.

Fenster, C.B., Armbruster, W.S., Wilson, P., Dudash, M.R., Thomson, J.D. 2004. Pollination syndromes and floral specialization. Annual Review of Ecology, Evolution and Systematics 35: 375-403.

Martén-Rodríguez, S., Fenster, C.B. 2010. Pollen limitation and reproductive assurance in Antillean Gesnerieae: a specialist vs. generalist comparison. Ecology 91(1): 155-165.

Molau, U. 1988. Scrophulariaceae-Part I. Calceolarieae. Flora Netropica 47: 1-326.

Murúa, M., Cisterna, J., Rosende, B. 2014. Pollination ecology and breeding system of two Calceolaria species in Chile. Revista Chilena de Historia Natural 87: 7.

Murúa, M., Espíndola, A. 2015. Pollination syndromes in a specialized plant-pollinator interaction: does floral morphology predict pollinators in Calceolaria? Plant Biology 17(2): 551-7.

Niemeyer, H.M., Bustamante, R.O., Simonetti, J.A., Teillier, S., Fuentes-Contreras, E., Mella, J.E. 2002. Historia natural de la reserva nacional Río Clarillo: un espacio para aprender ecología. Impresos Socías, Santiago, Chile. 361 pp.

R Development Core Team. 2015. R: A language and environment for statistical computing. R Foundation for Statistical Computing.

SÉrsic, A.N. 2004. Pollination biology in the genus Calceolaria L. (Calceolariaceae). Stapfia 82: 122.

Vogel, S.P. 1974. Ölblumen und ölsammelnde Bienen. Akademie der Wissenschaften und der Literatur, Tropische und Subtropische Pflanzenwelt 7: 1-267.

Wilcock, C., Neiland, R. 2002. Pollination failure in plants: why it happens and when it matters. Trends in Plant Science 7: 270- 277.

Recibido: 01.12.2015

Aceptado: 22.01.2018 